\title{
UNIVERSITY OF PENNSYLVANIA RADIOCARBON DATES XIII
}

\section{BARBARA LAWN}

Department of Physics and University Museum, University of Pennsylvania, Philadelphia, Pennsylvania 19104

\section{INTRODUCTION}

This date list includes those series of samples completed in this laboratory as of November 1969. The B.P. ages are based upon A.D. 1950, and are calculated with a half-life value of $5568 \mathrm{yr}$. All samples were counted at least twice for periods of not less than 1000 minutes each. Errors quoted are derived from measurement of samples, background, and modern-age calibration, but do not include any half-life error. All samples were pretreated with $3 \mathrm{~N} \mathrm{HCl}$, and some, where noted, were given additional pretreatment with $2 \% \mathrm{NaOH}$ for the removal of possible humic contaminants.

Standard calibration samples are 125-yr old oak samples which, when corrected for age, have $\mathrm{C}^{14}$ contents equal to $95 \%$ of the NBS oxalic acid standard. The $\mathrm{C}^{13}$ relationship between the oak standard and NBS limestone standard \#20 is $-25.7 \pm 1.3 \%$ as measured on the University of Pennsylvania mass spectrograph.

\section{SAMPLE DESGRIPTIONS}

\section{ARCHAEOLOGIC SAMPLES}

\section{A. Near East}

Iran

\section{Dinkha Tepe series, Iran}

Dinkha Tepe $\left(36^{\circ} 59^{\prime} 51^{\prime \prime} \mathrm{N}\right.$ Lat, $45^{\circ} 10^{\prime} 41^{\prime \prime} \mathrm{E}$ Long) is in the Ushnu Valley, W Azerbaijan, Iran. Samples coll. during 1966 and 1968 excavations at Dinkha Tepe, carried out by the Hasanlu Project, jointly sponsored by Univ. Mus., Univ. of Pennsylvania; Metropolitan Mus. of Art of New York City and Archaeol. Service of Iran; subm. by excavation director, R. H. Dyson, Jr., Univ. Mus., Univ. of Pennsylvania. Remains of 4 major occupations have been uncovered: Dinkha I (Islamic); Dinkha II (Iron Age II equal to Hasanlu IV, ca. 1000-800 в.C.); Dinkha III (Iron Age I equal to Hasanlu V, ca. 1350-1000 в.c.) and Dinkha IV (Bronze Age equal in part to Hasanlu VI, ca. ?1900-?1350 B.c.). This chronology is based on earlier radiocarbon dates from Hasanlu and studies of relative chronology (Dyson, 1965; Ralph, 1959; Stuckenrath, 1963; Stuckenrath et al, 1966).

\section{Dinkha III}

\section{P-1475. DiS 66-44, B7f(5)}

$3005 \pm 36$ 1055 B.C.

Charcoal immediately overlying Wall A, in Area B7, from top of central mound. Comment: $\mathrm{NaOH}$ pretreatment. 
P-1474. DiS 66-113, B8e(3)

$3157 \pm 55$

Charcoal from shallow pit over stone foundation of Wall E in Area B8, from top of central mound. Stratigraphically earlier than Wall A and P-1475. Comment: $\mathrm{NaOH}$ pretreatment.

\section{P-1449. DiS 66-52, B9a(7)}

$3099 \pm 71$

Charcoal from Test Trench 3 immediately above and resting on terminal Bronze age deposit (8), base of Dinkha III fill in Area B9 from $\mathrm{N}$ edge of central mound. Connecting trench to B8e shows (3) in that area to be closely related in time (cf. P-1474). Comment: NaOH pretreatment.

\section{Dinkha IV}

P-1231. DiS 66-54a, B9a(8)

$3285 \pm 50$

Charcoal from terminal Bronze age deposit (8) directly underlying Iron age fill (7) (cf. P-1449), ca. $1 \mathrm{~m}$ from $\mathrm{S}$ balk at $\mathrm{W}$ edge of Test Trench 3 in Area B9, $\mathrm{N}$ edge of central mound. Comment: $\mathrm{NaOH}$ pretreatment.

\section{P-1232. DiS 66-79, B10a $(8)$}

$3402 \pm 50$

Charcoal from main floor of final major Bronze age structure in Area $\mathrm{B} 10 \mathrm{a}(8), \mathrm{N}$ edge of central mound underlying terminal stratum $\mathrm{B} 9 \mathrm{a}(8)$ (cf. P-1231). Comment: $\mathrm{NaOH}$ pretreatment.

\section{P-1450. DiS 66-127, B10a $(8)[1]$}

$3434 \pm 61$ 1484 B.c.

Charcoal from burned structural beams in fill near floor of final major structure of Bronze age in Area B10a(8), N edge of central mound (cf. P-1232). Comment: $\mathrm{NaOH}$ pretreatment.

\section{P-1452. DiS 66-129, B10a(9)}

$3522 \pm 63$ 1572 в.c.

Charcoal from stratum of trashy fill, Area B10a(9), N edge of mound on which final Bronze age structure in this area stands (cf. P-1232 and P-1450). Tombs B27 and B28 dug into this level.

\section{P-1233. DiS 66-126a/2, G10g(2)}

$3458 \pm 59$

Charcoal from ashy fill (2) under clay floor (IA) and Walls G and $\mathrm{F}$ in Area G10g at $\mathrm{E}$ edge of central mound. Area not stratigraphically linked to preceding areas, but typologically (using ceramics) equal to $\mathrm{B} 10 \mathrm{a}(9)$ (cf. P-1452). Comment: $\mathrm{NaOH}$ pretreatment.

\section{P-1430. DiS 66-91, Hig(2)}

$3468 \pm 59$

Charcoal from floor assoc. with Wall D in Area Hlg at E end of central mound. Comparable stratigraphically to P-1233, below latest walls of probable Iron age in the area, and above earlier massive Wall H1h-E. Comment: $\mathrm{NaOH}$ pretreatment. 
P-1552. H1G

$3468 \pm 59$

1518 B.C.

Charcoal from room fill of Big Wall, Area HIG of E edge of central mound. Comment: $\mathrm{NaOH}$ pretreatment.

\section{P-1429/31. DiS 66-131/116, H1h(3)}

$3598 \pm 66$

Charcoal from floor to $\mathrm{N}$ of Wall $\mathrm{F}$ and from pit cut into Wall $\mathrm{G}$ from (3) in Area Hlh, E end of central mound. Walls F and G abutt top of earlier massive wall Hlh-E, dating to earlier half of Bronze age occupation. Should thus provide an ante quem date for this part of the period.

General Comment: (R.H.D.) dates recovered fit stratigraphic relationships of the samples very well and, using the 5730 half-life, indicate a general range of time for the later Bronze age occupation of $1756 \pm 68$ to 1434 \pm 52 B.c. with the following Iron Age I deposits between $1302 \pm 57$ and $1146 \pm 37$ в.c. Earlier part of Bronze age deposit must be prior to $1756 \pm 68$ в.c., but should be later than Hasanlu VII, radiocarbon dated to ca. 2100 B.c.

\section{Ganj Dareh Tepe series, Iran}

Ganj Dareh Tepe ("Mound of the Treasure Valley"), alt 1300 to 1400 $\mathrm{m}$, ca. $20 \mathrm{~km} \mathrm{~S}$ of Bisitun village in Kermanshah Dist., W Iran (34 $20^{\prime}$ $\mathrm{N}$ Lat, $47^{\circ} 30^{\prime} \mathrm{E}$ Long), is an early Neolithic stratified mound containing solid architecture and small quantities of simple software pottery in most levels. Samples coll. and subm. 1967 by P. E. L. Smith, Univ. of Montréal, Canada (Smith, 1967, 1968; Young and Smith, 1966; Kigoshi, 1967).

\section{P-1486. Square 17-0, depth 2.10 to $2.40 \mathrm{~m}$}

$8888 \pm 98$

Charcoal, Sample 67-27, from a room occupation floor in $\mathrm{W}$ part of Sq. 17-0, depth 2.10 to $2.40 \mathrm{~m}$ in what seems to be the 4 th building phase (Level B). Comment: NaOH pretreatment. Sample was expected to be approx. same age as, or slightly earlier than GaK-994, $8910 \pm 170$ B.P. (Radiocarbon, 1967, v. 9, p. 61).

\section{P-1485. Square 19-N, depth $4.50 \mathrm{~m}$}

$9239 \pm 196$

7289 B.C.

Charcoal, Sample 67-23, from SW corner of Sq. 19-N, depth 4.50 $\mathrm{m}$, from floor deposits inside walls of what is probably a room of the 2nd architectural phase (provisionally called Level C). Comment: date is probably less reliable than other 2 in this series, as sample was undersized, precluding $\mathrm{NaOH}$ pretreatment, and necessitating low pressure counting. Excavator believed this sample to be younger than GaK-807, 10,400 \pm 150 в.P. (from basal level in a 1965 sounding) but older than GaK$994,8910 \pm 170$ B.P. (Radiocarbon, 1967, v. 9, p. 61).

P-1484. Square 16-N(a), depth 6.20 m

$8968 \pm 100$

Charcoal, Sample 67-26, from Sq. 16-N(a), depth $6.20 \mathrm{~m}$, ca. $20 \mathrm{~cm}$ 
below a brick wall, at the base of the earliest certain architectural phase (Level D) but above basal deposits apparently lacking solid architecture (provisionally Level E). Comment: $\mathrm{NaOH}$ pretreatment. The level producing this sample is stratigraphically below the one producing P-1485.

\section{Godin Tepe series, W Iran}

Godin Tepe $\left(34^{\circ} 31^{\prime} \mathrm{N}\right.$ Lat, $48^{\circ} 3^{\prime} \mathrm{E}$ Long), in SE corner of the Kangovar Valley, at alt ca. $1400 \mathrm{~m}$ is mainly noteworthy for its long sequence, ca. 5500 to 600 B.c. and particularly for deposits of 2nd millennium в.C. Samples coll. by I. Winter and L. D. Levine; subm. by T. C. Young, Jr., Royal Ontario Mus., Univ. of Toronto (Young and Smith, 1966).

General Comment: all samples given $\mathrm{NaOH}$ pretreatment. For additional dates from levels stratigraphically below those of this list, see: GaK-1072, $4400 \pm 100$ в.P. and GaK-1071, $3860 \pm 120$ B.P. (Young, 1969).

\section{P-1469. Operation A1, Stratum 5, floor} terminal occupation level of Period III and should date approx. end of late Bronze age in central W Iran.

\section{P-1470. Operation A2, Stratum 5, Area 8}

Bits of charcoal and burned earth from floor debris of terminal occupation level of Period III and should date approx. end of late Bronze age in central $\mathrm{W}$ Iran.

\section{P.1471. Operation A1, Stratum 5A,} Area 5, Floor 2A

$2673 \pm 52$ 723 B.c.

Charred grain and burned earth from badly destroyed occupation level immediately beneath foundations of Period II fortification. Date should supply terminus post quem for Period II, ca. 800 в.c. Comment: slightly undersized sample, counted at $98.74 \%$ normal pressure.

\section{P-1472. Operation A1, Stratum 5A, $\quad 2550 \pm 53$ Area 5, Floor 2A \\ 600 B.c.}

Charcoal and burned earth from badly destroyed occupation level immediately below foundations of Period II fortification. Date should supply terminus post quem for Period II, ca. 800 B.c.

\section{Gedikli series}

\section{Turkey}

Gedikli (Karahöyük) ( $37^{\circ} \mathrm{N}$ Lat, $36^{\circ} 37^{\prime} \mathrm{E}$ Long), is a mound in Gaziantep Prov. of SE Turkey, revealing subsequent strata from Chalcolithic to Byzantine periods, whose early Bronze age cremation necropolis is of importance. Coll. 1966 by A. M. Dinçol and R. Özgürel and subm. by U. B. Alkim, Univ. of Istanbul (Alkim and Alkim, 1966; Mellink, 1965, 1966). 


\section{P-1461. C-trench, cremation area}

$\mathbf{3 8 7 7} \pm \mathbf{5 7}$

Charcoal from C-trench, cremation area, Samples 1, 2, and 3.

\section{B.c.}

\section{P-1464. Cremation vessel, C-trench}

Charred earth, fragments of bone and charcoal in cremation vessel, from ca. $2 \mathrm{~m}$ below surface of slope of mound, C-trench, cremation area, Sample 6.

\section{P.1463. $\quad A_{1}$-trench, IIIj}

$4267 \pm 65$

Charred grain from $\mathrm{A}_{1}$-trench, $\mathrm{IIIj}$, Sample 5 .

2317 B.C.

\section{P-1462. A A $_{1}$-trench, IIIK}

$4212 \pm 74$

Charred grain from $\mathrm{A}_{1}$-trench, IIIk.

2262 B.C.

\section{Dereagzí series, Turkey}

Dereagzi ( $36^{\circ} \mathrm{N}$ Lat, $29^{\circ} \mathrm{E}$ Long), is a middle Byzantine church near village of Dirginler (Kas Kazīsī, Antalya Vilâyeti), S Turkey. Both samples are from same beam of Cedrus libani (wood id. by B. F. Kukachka, Forest Products Lab., U.S. Dept. of Agric., Madison, Wisconsin) which should be contemporary with founding of church. Church can be dated between A.D. 843 and A.D. 907. Coll. and subm. 1967 by J. Morganstern, Inst. of Fine Arts of New York Univ., New York.

\section{P-1437. Sample 1}

$1156 \pm 44$

Wood from outer edge of beam.

\section{P-1438. Sample 2}

Wood from outer edge of beam, but cut penetrated more deeply into interior of beam than did P-1437.

General Comment: since the 2 dates are from the same region of a single beam, and the dates are statistically consistent, an average age of A.D. $754 \pm 36$ can be used.

\section{P-1395. Yassi Ada Shipwreck}

\section{A.D. 1617}

$333 \pm 44$

Wood from hull of extremely well-preserved shipwreck of unknown date, overlying part of Late Roman shipwreck in $195 \mathrm{ft}$ water at Yassi Ada, Turkey ( $36^{\circ} 59^{\prime} \mathrm{N}$ Lat, $27^{\circ} 12^{\prime} \mathrm{E}$ Long). Coll. and subm. 1967 by G. F. Bass, Univ. Mus., Univ. of Pennsylvania, Philadelphia.

\section{Tell es-Sa'idiyeh series, Jordan}

\section{Jordan}

Tell es-Sa'idiyeh $\left(32^{\circ} 16^{\prime} \mathrm{N}\right.$ Lat, $35^{\circ} 35^{\prime} \mathrm{E}$ Long), lies ca. $2 \mathrm{~km} \mathrm{E}$ of Jordan R., immediately S of Wadi Kufrinje, Jordan. Coll. 1965 and 1966 during excavation of higher mound and subm. by J. B. Pritchard, Univ. Mus., Univ. of Pennsylvania, Philadelphia. Samples are from floors 
within a complex of buildings believed, on basis of tentative estimate for date of pottery, to have been destroyed during the centuries noted below (Pritchard, 1964a, b; 1965a, b, c; 1966a, b).

Acropolis series, Floor of Hellenistic building, 2nd century B.c.

\section{P-1095. Area 31-C-7, Floor 1}

Wood from roof beam.

P-1096. Area 31-B-8, South balk

Wood from burnt beam.

\section{P-1097. Area 31-B-8}

Charcoal from beam.

P-1098. Area 31-B-6

Charcoal from beam.

\section{P-1447. Area 31-B-6}

$$
2098 \pm 55
$$

148 B.C.

$2199 \pm 55$

249 B.C.

$2179 \pm 53$ 229 B.c.

$2267 \pm 53$

317 B.c.

$2228 \pm 48$

Charcoal, over Floor 1.

General Comment: all samples received $\mathrm{NaOH}$ pretreatment. The 5 dates are statistically consistent, with an average date of $244 \pm 53$ в.c.

Floor of "Persian" Palace, 3rd or 4th century B.c.

P-1446. "Persian" palace, Area 31-E-6

$2226 \pm 50$

276 в.C. treatment.

Charcoal from "Persian" palace, Floor 1c. Comment: $\mathrm{NaOH}$ pre-

Below "Persian" palace series

P-1442. Area 31, Room 8/7 (W)

$2415 \pm 54$

Grain, $\mathrm{N}$ sec., along $\mathrm{E}$ wall.

P-1443. Area 31, Room 5/4

$2310 \pm 100$

Charcoal, clearing furnace, below jar in $\mathrm{N}$ sec. of furnace. Comment: this date is of single count only.

P-1445. Area 31-E-7, Floor 3

$2141 \pm 55$

Grain, (House $4 \mathrm{~N}$ of $\mathrm{S}$ sec. of kiln).

191 B.C.

P-1448. Area 31-E/F-7/8, Room 5/1W

Grain, $\mathrm{N}$ sec. along $\mathrm{E}$ wall on or above floor.

535 B.C.

General Comment: all samples in this series received $\mathrm{NaOH}$ pretreatment. Omitting, P-1445, remaining 3 dates are statistically consistent, with average date of $453 \pm 73$ в.c. 
Trench series, Level 2, 8th century B.c.

P-1100. Area 23-E-3

$2424 \pm 57$

474 B.c.

Charcoal from beam, near E wall of back room on Floor II. Comment: compare P-1100 with P-832, $2406 \pm 52$ and P-385, $2418 \pm 54$ (Radiocarbon, 1965 , v. 7, p. 195). These 3 dates are statistically consistent, with average date of $466 \pm 54$ B.c.

P-1099. Area 23-G-2

$2577 \pm 53$

Charcoal. Comment: $\mathrm{NaOH}$ pretreatment.

627 B.C.

P-1101. Area 23-G-4

$2609 \pm 58$

659 B.C.

Charcoal from beam. Comment: $\mathrm{NaOH}$ pretreatment.

\section{P-1444. Area 23-G-4, Floor 2}

$2633 \pm 60$

683 B.C.

Charcoal from Floor 2. Comment: $\mathrm{NaOH}$ pretreatment.

General Comment: compare P-1099, P-1101, and P-1444 with P-829, 2596 \pm 56; P-830, $2572 \pm 59 ;$ P-831, $2542 \pm 46 ;$ P-839, $2537 \pm$ 52; P-834, $2726 \pm 157$; and P-836, $2523 \pm 53$ (Radiocarbon, 1965, v. 7, p. 195). These 9 dates are statistically consistent, with average date of $640 \pm$ 55 B.C.

\section{Lebanon}

\section{Cedars of Lebanon series, Lebanon}

Wood (Cedrus libani) from structures dating to early Egyptian dynasties suggested dendrochronologic correlation among several structures; also, since wood was imported originally from the Levant, possible correlation with samples found in that part of the Mediterranean. "Buried" cedar sample of sufficient antiquity (see P-WA-LEB-1), was obtained, but proved unusable for dendrochronologic purposes as ring pattern was complacent. Another sample from allegedly old specimen proved too recent to be of value for this type of correlation (see P-WA-LEB-2).

\section{Cedars of Lebanon (P.WA-LEB-1)}

Cross sec. of Cedrus libani buried in landslide near Chkiff, Lebanon, ca. (35 $51^{\prime} \mathrm{N}$ Lat, $35^{\circ} 45^{\prime} \mathrm{E}$ Long). Uncovered during re-terracing in 1962. Sec. coll. 1964 and subm. by H. N. Michael, Univ. Mus., Univ. of Pennsylvania, Philadelphia.

P-890. Pith, Rings 1 to 16

$2901 \pm 44$

$\delta \mathrm{C}^{13}=+0.5 \%$ from Oak standard.

951 B.c.

P-891. Rings 16 to 23

$3133 \pm 36$

$\delta \mathrm{C}^{13}=0 \%$ from Oak standard.

1183 B.C. 


\section{P-892. Rings 184 to 188}

$\delta \mathrm{C}^{13}=-1.8 \%$ o from Oak standard. Comment: compare with I-512, $2560 \pm 150$ B.P. (Troutman, 1965, written commun.).

\section{P-1089. Cedars of Lebanon (P-WA-LEB-2)}

$\mathbf{0} \pm \mathbf{1 0 0}$

Cross sec. from trunk (Cedrus libani) found in cave several mi $\mathrm{N}$ of "les Cedres", Lebanon, (ca. 34 $20^{\prime} \mathrm{N}$ Lat, 36 $10^{\prime} \mathrm{E}$ Long). Coll. 1965 by G. Wahbé, Beirut; subm. by H. N. Michael. Sample was taken from sec. 20 rings inside of bark.

\section{P-1025. Cedars of Lebanon (P.EG-DAS-1)}

$4290 \pm 56$

Wood ("floater", Cedrus libani) from floor of upper chamber of Bent Pyramid at Dashur $\left(29^{\circ} 45^{\prime} \mathrm{N}\right.$ Lat, $31^{\circ} 12^{\prime} \mathrm{E}$ Long), at one time integral part of a beam bracing lower part of upper chamber (Fakhry, 1959, p. 52-59, pls. XII, XIII; Fakhry, 1961, p. 88-94). Presumably assoc. with construction of pyramid during reign of Sneferu (2680 to 2656 B.C.). Coll. 1965 and subm. by H. N. Michael.

\section{B. Mediterranean \\ Greece}

\section{Mycenae series, Argolis, Greece}

Samples are from Citadel House at Mycenae $\left(37^{\circ} 44^{\prime} \mathrm{N}\right.$ Lat, $22^{\circ} 44^{\prime}$ E Long) Argolis, Greece. Coll. 1964 and 1966 during excavation by British School at Athens; subm. by Lord Wm. Taylour, British School at Athens.

P-1454. Gamma 21, No. 7

Carbonized matter from pure Mycenean level, 923 B.c. levels removed.

\section{P.1455. Gamma 23, No. 5}

Charcoal from $\mathrm{NaOH}$ pretreatment.

P-1456. Gamma 23, No. 6

$3035 \pm 65$

Charcoal from pure destruction level of 13 th centur $\mathrm{NaOH}$ pretreatment.

\section{P-1457. Gamma 23, No. 9}

Fragments of burnt beam from what appears to be 13th century B.c. destruction level. Comment: $\mathrm{NaOH}$ pretreatment.

P.1459. Gamma 22, No. 1

$2961 \pm 50$

Charcoal from Mycenean level.

1011 B.c. 


\section{Italy}

\section{P.1432. Le Muraglie}

$2243 \pm 48$ 293 B.C.

Wood charcoal (id. by B. F. Kukachka, Forest Products Lab., U.S. Dept. of Agric., Madison, Wisconsin, as of white oak group), from Excavation 5 assoc. with crude walls (possibly Greek) underlying Roman structure at Le Muraglie, a low plateau on SE perimeter of plain of Sybaris, Cosenza, Italy (39 $49^{\circ} \mathrm{N}$ Lat, $16^{\circ} 33^{\prime} \mathrm{E}$ Long). Coll. 1964 and subm. by E. K. Ralph, Univ. Mus., Univ. of Pennsylvania, Philadelphia (Rainey and Lerici, 1967, p. 198-199).

\section{P-1435. Pantano Longarini Wreck}

$1328 \pm 48$

The Pantano Longarini wreck $\left(36^{\circ} 19^{\prime} \mathrm{N}\right.$ Lat, $15^{\circ} 8^{\prime} \mathrm{E}$ Long) near Cape Passaro-Pachino, SE cape of Sicily, was found during winter 19631964 , in salty marsh $600 \mathrm{~m}$ from present shore line, while digging drainage canal as part of reclaiming operation. Sample coll. 1965 and subm. by P. Throckmorton, Univ. Mus., Univ. of Pennsylvania, Philadelphia. Wood id. as cyparissus semiviperens by B. F. Kukachka. Previous sample from this wreck, dated in Germany, dated at A.D. $500 \pm 150$ and "combed pottery" finds indicate date of 4 th to 6th century A.D. (Throckmorton and Kapitan, 1968).

\section{P-1436. Torre Sgarrata Wreck}

$2027 \pm 43$

77 в.c.

Torre Sgarrata (Sassole) wreck, near Taranto, Italy $\left(40^{\circ} 14^{\prime} \mathrm{N}\right.$ Lat, $17^{\circ} 13^{\prime}$ E Long) was originally located by fishermen before World War I because some marble sarcophagi of the cargo was visible through $10 \mathrm{~m}$ water when storms swept away sand covering site. Sample coll. and subm. 1965, by P. Throckmorton during survey explorations of different wrecks along coast between Porto Caesareo and Taranto. Wood id. as Pinus Halepensis by B. F. Kukachka. Small finds indicate date ca. 200 A.D. for time of actual sinking (Throckmorton, 1969).

\section{P-1056. Site X, Galli Islands, Salerno}

$2161 \pm 39$

211 B.c.

Wooden core from lead anchor stock, recovered from $35 \mathrm{~m}$ water at Site X, Galli Is., Salerno, Italy (40 $34^{\prime} 46^{\prime \prime} \mathrm{N}$ Lat, $14^{\circ} 26^{\prime} 1^{\prime \prime}$ E Long). Coll. 1964 by R. E. L. Love, Jr. and Col. J. D. Lewis; subm. 1965 by J. D. Lewis, Naval War College, Newport, Rhode Island. Wood id. as one of several live oak (Quercus) types growing in Mediterranean region by B. F. Kukachka. Comment (J.D.L.): lead-stocked anchors were in use from 300 B.c. to ca. 400 A.D. (Love and Lewis, 1964; Torr, 1964; Frost, 1963; Casson, 1960; Ucelli, 1950).

\section{Southwest Asia Afghanistan}

\section{Ghar-i-Mar series, Afghanistan}

Ghar-i-Mar (Snake Cave) is a rock shelter, on a high terrace of the 
Balkh R. in limestone hills of Hindu Kush Mts, ca. $100 \mathrm{~km} \mathrm{~S} \mathrm{of} \mathrm{Mazar-i-}$ Sharif near the town of Aq Kupruk (36 $5^{\prime} \mathrm{N}$ Lat, $66^{\circ} 51^{\prime} \mathrm{E}$ Long). Samples coll. 1962 by L. Dupree and subm. by R. Dyson, Univ. Mus., Univ. of Pennsylvania, Philadelphia. For additional dates from this site see Hv-425, $8650 \pm 100 ; \mathrm{Hv}-426,1390 \pm 60 ; \mathrm{Hv}-427,1340 \pm 70 ; \mathrm{Hv}-428$, $7220 \pm 100$; and $\mathrm{Hv}-429,7030 \pm 110$ (Radiocarbon, 1964, v. 6, p. 263264; Coon, 1957; Dupree, 1959, 1964).

General Comment: all samples given $\mathrm{NaOH}$ pretreatment.

P-1489. Trench I, Cut la

Charcoal: Upper Red Earth.

P-1490. Trench I, Cut 5n

Charcoal: 220-Red Loess above Upper Gravels.

\section{P-1491. Trench I, Cut 6 p}

Charcoal: 130-Red Loess above Upper Gravels.

\section{P-1492. Trench I, Cut 6q}

Charcoal: 130-Red Loess above Upper Gravels.

\section{P-1493. Deh Morasi Ghundai}

Charcoal and fire-burned earth from 300 to $320 \mathrm{~cm}$ level of Del Morasi Ghundai (31 $35^{\prime} \mathrm{N}$ Lat, 65 $35^{\circ} \mathrm{E}$ Long) a Chalcolithic site in S-central Afghanistan. Coll. 1951 and subm. 1960 by L. Dupree (1963). Date was expected to be comparable to that from Mundigak, C-815, 4625 \pm 300 (Libby, 1955).

\section{Kagnout series, Senegal}

\section{Africa}

Senegal

Lo-Oul-6 (Loudia-Oulof), Mound A, located inland near village of Kagnout $\left(42^{\circ} 33^{\prime} \mathrm{N}\right.$ Lat, $16^{\circ} 37^{\prime} \mathrm{W}$ Long), is one of archaeol. sites consisting of artificial shell-middens in broad delta region of the lower Casmanance R. in the SW corner of Senegal. Coll. 1966; subm. by O. Linares de Sapir, Dept. of Anthropol., Univ. of Pennsylvania, Philadelphia. Dates for 2 other sites, Lo-Oul-1: Si-489, $369 \pm 68$; Si-490, $893 \pm$ 49; Si-491, $311 \pm$ 97; Si-492, $476 \pm$ 49; Si-493, $573 \pm$ 136; Si-494, modern; Si-495, $379 \pm 68$; Si-496, $2087 \pm 68$ and Di-3: Si-497, $320 \pm 49 ;$ Si-499, $1631 \pm 78$ (Linares de Sapir, 1969, written commun., 1969a, b).

P-1478. 40 to $70 \mathrm{~cm}$

Charcoal, combined Samples 285-287.

P-1479. 70 to $100 \mathrm{~cm}$

Charcoal, combined Samples 288-290.

$$
1226 \pm 50
$$

A.D. 724

$$
1197 \pm 45
$$

A.D. 753 
P-1480. 100 to $110 \mathrm{~cm}$

$1175 \pm 50$

Charcoal, Sample 291.

P.1481. 110 to $130 \mathrm{~cm}$

A.D. 775

Charcoal, Samples 292 and 293.

$1292 \pm 52$

A.D. 658

P-1482. 130 to $150 \mathrm{~cm}$

$1263 \pm 51$

Charcoal, Samples 294 and 295.

A.D. 687

\section{P-1483. 150 to $170 \mathrm{~cm}$}

$1606 \pm 50$

Charcoal, Samples 296 and 297.

A.D. 344

General Comment: excluding P-1483, A.D. 344, remaining dates are statistically consistent, with average date of A.D. $719 \pm 50$, chronologically placing this shell-midden within Casmanance Period II, ca. $344 \pm 50$ to A.D. $719 \pm 50$.

E. Far East

\section{Thailand}

\section{Chansen series, Thailand}

Main occupation of Chansen ( $15^{\circ} 7^{\prime} \mathrm{N}$ Lat, $100^{\circ} 27^{\prime} \mathrm{E}$ Long), Takli Dist., Nakhon Province, Thailand, belongs to Dvaravati period (ca. 6th to 10 th century A.D.), earliest historic period of Thailand. Samples in this series are all pre-Dvaravati, coll. 1968 and subm. by G. F. Dales, Thailand Fine Arts Dept. and Univ. Mus., Univ. of Pennsylvania, Philadelphia.

\section{P-1507. Operation B, Level 8}

$$
1580 \pm 50
$$

Charcoal, Sample 1, from Operation B, Level 8 (3 m sq. test pit), 145 to $164 \mathrm{~cm}$ beneath surface, in 5 th natural stratum from surface, partly sealed by layer of hardpan. Comment (G.F.D.): this sample cannot be ordered in stratigraphic relation to the other samples, as area was badly disturbed by modern pot-hunting.

P-1540. Operation C, Level 6

$1573 \pm 35$

Charcoal, Sample 8. Comment: $\mathrm{NaOH}$ pretreatment.

\section{P.1541. Operation C, Level 7}

$1595 \pm 52$

Charcoal, Sample 9, $190 \mathrm{~cm}$ beneath ground surface. Comment: $\mathrm{NaOH}$ pretreatment.

P-1509. Operation C, Level 7, hearth

$$
1503 \pm 43
$$

Charcoal, Sample 3, W side of excavations, 204 to $210 \mathrm{~cm}$ beneath ground surface. Comment: $\mathrm{NaOH}$ pretreatment. 


\section{P-1538. Operation C, Level 7}

$1540 \pm 47$

Charcoal mixed with powdery ash, Sample 4, from same hearth as $\mathrm{P}-1509,210$ to $215 \mathrm{~cm}$ beneath ground surface. Comment: $\mathrm{NaOH}$ pretreatment.

\section{P-1539. Operation C, Level 7}

$1491 \pm 47$

Charcoal, Sample 5, from bottom of same hearth as P-1509 and $\mathrm{P}-1538,215$ to $220 \mathrm{~cm}$ beneath ground surface. Comment: $\mathrm{NaOH}$ pretreatment.

\section{P-1543. Operation C, Level 7}

$2145 \pm 36$

Charcoal, Sample 10, in small pit large animal bone. Comment: $\mathrm{NaOH}$ pretreatment.

\section{P-1508. Operation C, Level 9}

$1830 \pm 47$

Charcoal, Sample 2, from control pit in SE corner, 220 to $230 \mathrm{~cm}$ beneath ground surface. Stratigraphically sealed beneath layer of marl and concretion, $200 \mathrm{~cm}$ beneath ground surface. Comment: NaOH pretreatment.

\section{P-1512. Operation D, a, Level 9}

$1890 \pm 41$

Charcoal, Sample 6, from "midden" deposit containing a smashed skull and snail shell $225 \mathrm{~cm}$ beneath ground surface. Comment: $\mathrm{NaOH}$ pretreatment. (G.F.D.): assoc. with ivory comb which is earliest known ivory object from Thailand.

II. GEOLOGIC SAMPLE

\section{A. Scandinavia \\ Finland}

\section{P.1542. Linnansuo Bog}

$5183 \pm 56$

Wood from core of Linnansuo Bog, market town of Imatra, Finland $\left(61^{\circ} 11^{\prime} \mathrm{N}\right.$ Lat, $28^{\circ} 48^{\prime} \mathrm{E}$ Long), from top of peat layer, beneath clay formed on bog at time of formation of present outlet (Vuoksi R.) of Lake Saimaa. According to pollen analysis this occurred earlier than Zone Boundary VIII/IX (Hellaakoski, 1936; Lappalainen, 1962). Coll. 1967 by M. Saarnisto; subm. by J. J. Donner, Univ. of Helsinki, Finland.

\section{REFERENCES}

Alkim, U. B. and Alkim, H., 1966, Excavations at Gedikli (Karahöyük)-First preliminary report: Belletin, v. 30, p. 177.

Casson, Lionel, 1960, The Ancient Mariners: London, Macmillan, 286 p.

Coon, C. S., 1957, The Seven Caves: New York, Knopf, 338 p. Dupree, Louis, 1959, Shamshir Gar: Anthropol. Papers Am. Mus. Nat. History, v.
46, pt. 2, p. 299-304.

1963, Deh Morasi Ghundai: a Chalcolithic site in south-central Afghanistan: Anthropol. Papers Am. Mus. Nat. History, v. 50, pt. 2, p. 57-136. 
Dupree, Louis, 1964, Prehistoric archaeological surveys and excavations in Afghanistan: 1959-1960 and 1961-1963: Science, v. 146, no. 3644, p. 638-640.

Dyson, Jr., Robert, 1965, Problems of Protohistoric Iran as seen from Hasanlu: Jour. Near Eastern Studies, v. 24, p. 193-217.

Fakhry, Ahmed, 1959, The Bent Pyramid: The Monuments of Sneferu at Dashur, v. 1: Cairo, Egypt, Gen. Org. Govt. Printing Office.

1961, The Pyramids: Chicago, Univ. of Chicago Press, $260 \mathrm{p}$.

Hellaakoski, A., 1936, Das Alter des Vuoksi: Comm. Geol. Finlande Bull., v. 115, p. 31.

Kigoshi, Kunihiko, 1967, Gakushuin natural radiocarbon measurements VI: Radiocarbon, v. 9, p. 43-62.

Lappalainen, V., 1962, The shore-line displacement on southern Lake Saimaa: Bot. Fennica Acta, v. 64, p. 125.

Libby, W. F., 1955, Radiocarbon dating, 2nd ed.: Chicago, Univ. of Chicago Press, ix, $175 \mathrm{p}$.

Linares de Sapir, Olga, 1969a, Shell middens of Lower Casmanance and problems of Diola Prehistory: W. African Jour. of Archacol., v. 1, in press. 1969b, Diola pottery of the Fogny and Kasa: Expedition, v. 11, p. 2-11.

Love, Jr., R. E. L. and Lewis, J. D., 1964, Report of recovery of antiquities from Site X in the Gulf of Salerno: ms. on file, Supt. Antiquities, Prov. of Salerno, Italy.

Mellink, M., 1965, Anatolian Chronology: chronologies in old world archaeology, Chicago, Univ. of Chicago Press, p. 123. 279-280. ritchard, J. B., 1964a, Excavating a Biblical site in Jordan: Illus. London News, v. 244, no. 6504 , p. $487-489$. no. 4, p. $2-9$. Two Tombs and a Tunnel in the Jordan Valley: Expedition, v. 6, p. $10-17$.

1965a, First excavations as Tell es-Sa'idiyeh: Biblical Archaeologist, v. 28, 1965b, Cosmopolitan Culture of the Late Bronze Age: Expedition, v. 7, no. 4 , p. $26-33$.

1965c, Chronique Archaeologique: Rev. Biblique, v. 72, p. 257-262.

1966a, Three ages of Biblical Zarethan: Illus. London News, v. 246, no. 6622 , p. $25-27$.

1966b, Chronique Archaeologique: Rev. Biblique, v. 73, p. 574-576.

Ralph, E. K., 1959, Univ. of Pennsylvania radiocarbon dates III: Radiocarbon, v. 1, p. $45-58$. Rainey, F. G. and Lerici, C. M., 1967, The search for Sybaris: Rome, Lerici Editori,

Smith, P. E. L., 1967, Survey of excavations in Iran during 1965-66: Ghar-i Khar and Ganj-i-dareh Tepe: Iran, v. 5, p. 138-139.

1968, Survey of excavations in Iran during 1967: Ganj Dareh Tepe: Iran, v. 6 , p. $158-160$

Stuckenrath, R., Jr., 1963, Univ. of Pennsylvania radiocarbon dates VI: Radiocarbon, v. 5 , p. $82-103$.

Stuckenrath, R., Jr., Coe, W. R., and Ralph, E. K., 1966, Univ. of Pennsylvania radiocarbon dates IX: Radiocarbon, v. 8, p. 348-385.

Throckmorton, Peter, 1969, Ancient shipwreck yields new facts and a strange cargo: Natl. Geographic, v. 135 , no. 2, p. 282-300.

Throckmorton, Peter and Kapitän, Gerhard, 1968, An ancient shipwreck at Pantano Longarini: Archaeology, v. 21, no. 3, p. 182-187.

Torr, Cecil, 1964, Ancient Ships: Chicago, Argonaut, 222 p.

Ucelli, Guido, 1950, Le Navi Di Nemi: Rome, La Libreria Dello Stato, 424 p.

Young, Jr., T. C., 1969, The Chronology of the late third and second milennia in central western Iran as seen from Godin Tepe: Am. Jour. Archaeol., v. 73, no. 3, p. 287-291.

Young, Jr., T. C. and Smith, P. E. L., 1966, Research in the Prehistory of central western Iran: Science, v. 153, no. 3734, p. 386-391. 